\title{
Community Participation Model for Prevention and Control of Diabetes Mellitus
}

\author{
Víctor Manuel Mendoza-Núñez, María de la Luz \\ Martínez-Maldonado and Elsa Correa-Muñoz \\ Unidad de Investigación en Gerontología, Facultad de Estudios Superiores Zaragoza, \\ Universidad Nacional Autónoma de México (UNAM), México D.F., \\ México
}

\section{Introduction}

The health of the population is a product of the society and at the same time an indispensable contribution to economic growth and political stability. The degree of health of the population is a very important indicator of human development. In this regard, it is necessary for the Ministry of Health to forge alliances with other public and private actors, including organizations of the civil society, because it has been shown recently that one of the key elements that contribute to maintenance of health is the support that is received from interpersonal interaction.

At present, there has been a significant increase worldwide of chronic degenerative diseases, among which Diabetes mellitus (DM) is prominent.

Diabetes mellitus constitutes a public health problem worldwide. In this respect, the International Diabetes Federation estimates that 285 million people around the world suffer from DM. This total is expected to rise to 438 million within 20 years. Each year, an additional seven million persons develop diabetes (International Diabetes Foundation [IDF], 2011). This disease is the leading cause of death in Mexican population and is the most cost-intensive item for the nation's health care system. The majority of patients with diabetes in Mexico are in poor metabolic control (Villalpando et al., 2010a). In this respect, the current care model has not been effective for the prevention and control of DM. Thus, it is necessary to develop feasible strategies for adapting the current care model into a context of shared responsibility between the community and the health-team system (Villalpando et al., 2010b).

In this chapter, we present a community participation model for the prevention and control of diabetes mellitus. This model establishes as its fundamental strategy the implementation of a formal health-promoters training program so that program participants will achieve empowerment and constitute a social capital of benefit to themselves through active participation in the community with the practice of self-care, mutual aid, and self-promotion in an organized and systematic social network (Mendoza-Núñez et al., 2009a). For management of diabetes mellitus in the community, the following are established as key elements: (i) adoption of healthy lifestyles; (ii) treatment individualization and health promotion strategies, (iii) aggressive prevention and management of risk factors, and (iv) rigorous glycemic control as an element of prevention and management (Mendoza-Núñez \& Rosado-Pérez, 2010). 


\section{Health concepts}

Health is a fundamental quality of the human being, who is a biological, living, dynamic, and unique being; a social being who is in permanent interaction with other human beings, situated in a time and space that depend on their environment and that act on it; a being of emotions, of sensations, of desires, of intentions; a spiritual being; a being of knowledge, of rationality, of reflection. Therefore, health will be expressed in each of these dimensions (Contandriopoulos, 2006).

On the other hand, in order to understand the determinants of the wellness-sickness of individuals and populations, it is necessary to explore the biological, social, and psychic spaces of humans. Each of these dimensions constitutes a viewpoint on wellness-sickness and on the factors affecting this. None of these dimensions is independent of the others, nor is any sufficient for summarizing the significance of health and what the determinants of the latter are.

It is also important to recognize that the protection or promotion of the population in the broadest sense cannot constitute a responsibility that the society delegates to one institution in particular (a health system, or a private group: physicians; social workers; community groups, etc.). This should be assumed by the entire society and depends on the capacity of the State to guarantee access to education, health services, safety, and a healthy environment. In these terms, health is the concern of each of the citizens (Contandriopoulos, 2006).

The manner of conceptualizing health and disease should evolve so that it is not only the result of consensuses of normality and abnormality, of statistical tables or measurements by techno-scientific apparatuses, but rather, the result of a dialog in which the scientific, subjective, and contextual aspects of biopsychosocial humans participate (Caponi, 1997).

On the other hand, it is important to recognize that the human, as are all living beings, is an integrated whole that constitutes a dynamic suprasystem, which is in turn comprises the following many perfectly coordinated subsystems: the physical subsystem; the chemical; the biological; the psychological; the social; the cultural; the ethico-moral, and the spiritual. All of these, together and integrated, constitute the personality, and their lack of integration or coordination unleashes pathological processes of different natures: organic; psychological; social, or several together.

Within this context, the definitions of health, as with other human qualities, are generated at specific historical moments and are linked with the social and economic circumstance under which the spaces for application of this definition gain in practice, signify the way to obtain power to overcome this particular circumstance; thus, these definitions cannot be more than historically perishable. Notwithstanding its transitory situation, the way of looking at health by those wielding power over more or less extensive population groups defines the way of acting in relation to their health and the purposes and forms of utilizing their resources (Chapela, 2008a).

In this work, we understand health as "the capacity of the human corporeal nature to decide and contract viable futures and of reaching these". This definition of health, on the one hand, conceives of the subject as body-subjectivity, that is, as only one thing, and on the other, sets forth a cross-disciplinary and multi-conceptual position on health and ponders the subject in collective fashion (Chapela, 2008a).

This definition allows us to disassociate health from sickness, to understand that the former is an essential part of the subject and not solely a state or a moment in life. The latter term 
shows us that the subject has a great deal to do with the construction of health at the individual as well as at the collective level, without forgetting that the human corporeal-nature capacity of deciding and constructing futures is mediated not only by the individual's world vision, by history, that is, by past, present, and future happenings that have permeated the person's being and the individual's being in the world, but also by the social guidelines that structure the ways that subjects proceed, without forgetting the psychobiological dimension in which aspirations, wishes, sensations, and emotions, and, of course, actions take place, having the political and economic dimensions as a framework (Chapela, 2008a).

\section{Health Promotion (HP)}

The notion of HP is also complex and controversial, and to date, a consensus has not been reached with regard to its significance. HP is a relatively recent notion and acquired importance during the mid-XX Century. However, throughout history we are able to find practices and conceptions directed toward improving the conditions of life of the people that, in the light of present-day conceptions and values, could be recognized as antecedents of HP, although with significant differences (Restrepo, 2001; Gómez-Arias and González, 2004; Eslava- Castañeda, 2006; Chapela, 2008b).

According to the Ottawa Charter, HP is a process that permits people to increase control over their health to improve it. It constitutes a political, social, and global progression that encompasses not only actions directed precisely toward strengthening the abilities and capacities of individuals, but one that is also directed toward modifying social, environmental, and economic conditions with the aim of mitigating their impact on public and individual health. HP is the process that allows people to increase their control over the determinants of health and, consequently, to improve it. Participation is essential to sustain action in matters of health promotion (Ottawa Charter for the Promotion of Health, World Health Organization [WHO] Geneva, Switzerland 1986).

However, after Ottawa, multiple health promotions may be found in distinct countries and practiced by distinct international organizations, although these affirm that they have adopted the Ottawa Charter as their directorate. The original concept that is planned in the document involves conducting changes in many structural instances; however, not all of the organisms that have understood the document are disposed to change; thus, the actions in many cases have been very restricted (Chapela 2008b).

\section{Community models for the prevention and control of diabetes mellitus}

In the past decades, the implementation of community programs for the prevention and control of DM has been a priority worldwide (Shephard et al., 2005; Castillo, 2010; Ciccone et al., 2010). In this regard, the study published by Wagner et al. in 1996 permitted determination of the common elements of community programs for chronic disease control with the participation of the community, which allowed for developing the so-called "The Chronic Care Model (CCM)". The CCM focuses on improving and optimizing six key elements of the health care system: i) health care organization; ii) delivery system design; iii) clinical information systems; iv) decision support; v) self-management support, and vi) community resource linkages. The usefulness of this model has been widely demonstrated for the prevention and control of DM (Wagner et al., 1996; Wagner et al., 1999; Glasgow et al., 2001 Parchman et al., 2007; Piatt et al., 2006; Battersby et al., 2010; Strickland et al., 2010). 
Although the usefulness of the CCM is widely recognized for the prevention and control of chronic diseases, the need has been recognized to broaden, modify, or adapt it, taking into consideration the specific needs of the population; therefore, some options, one denominated the Expanded Chronic Care Model (ECCM), have been proposed (Barr et al., 2003). Among the best known proposals, we are able to cite Racial and Ethnic Approaches to Community Health (REACH) (Giachello et al., 2003; Jenkins et al., 2010) and Communitybased Participatory Research (CBPR) (Savage et al., 2006; Horowitz et al., 2009).

In Latin America, the Program for Education of Non-insulin-dependent Diabetics-Latin America (PEDNID-LA) was proposed, which was implemented simultaneously in Argentina, Bolivia, Brazil, Chile, Colombia, Costa Rica, Cuba, Mexico, Paraguay, and Uruguay, demonstrating satisfactory results for the adoption of healthy lifestyles (Gagliardino \& Etchegoyen, 2001).

In Mexico, the Ministry of Health's General Directorate of Health Promotion developed the Health Promotion Operational Model in 2006. Based on Ottawa Charter functions, the model integrates health promotion activities within the overall health care system (SantosBurgoa et al., 2009). However, the results relative to the implementation and effectiveness of the model have not been reported.

The National Autonomous University of Mexico (UNAM, FES-Zaragoza Campus) has developed a model for the prevention and control of chronic diseases that is directed toward older adults (Mendoza-Núñez et al., 1996; Martínez-Maldonado et al., 2007, MendozaNúñez et al., 2009a); notwithstanding this, its application is not limited to this age group, but rather, can be useful for the adult population in general.

The model is based fundamentally on the integral development of the person, understood as a process that is carried out throughout and until the end of the person's lifetime. It implies becoming active in many ways, making use of and potentiating the resources possessed. It is a process of transformation and continuous growth in which the social capital is fundamental. Integral development involves the following elements: citizenship; social capital; potentialities; social networks, and empowerment.

a. The concept of citizenship, which makes relevant the fact of "being subject to" with rights (rights to life, freedom, dignity, health, well-being, etc.) and of being able to make use of these.

b. Social capital, which permits the potential exchange of the opportunities of a social support network.

c. The concept of potentialities, which all of us human beings possess physically (functional efficiency, muscular force, and motor skills), psychologically (sensitivity, affect, knowledge acquisition, creativity, etc.), and socially (links, productivity, social participation, the creation of culture and values, etc.).

d. Social support networks, by means of which, through personal, community, and institutional contacts, the individual maintains his/her identity and his social development.

e. Empowerment, the process of participative development through which individuals, communities, and organizations achieve greater control over their lives and environment.

\section{Social support networks and health}

The study of social support and its repercussions on the state of health, well-being, and Quality of life (QOL) has experienced significant development dating from the last three 
decades of the XX Century, above all in some related disciplines, such as preventive medicine, public health, community psychology, social work, anthropology, and sociology. Notwithstanding this, self-help groups, as they are now known, arose in the 1930s in the U.S. with the foundation of Alcoholics Anonymous (AA) (Llopis, 2005).

Social networks refer to the personal, community, and institutional contacts through which the individual maintains his/her social identity and receive material, instrumental, emotional, and informative support. The basic elements of social support networks comprise social capital, which is defined as the potential exchange of opportunities of a social network. Therefore, social capital depends in large measure on the social contacts possessed by the individual (Burt, 1997). Likewise, social support represents the tangible element of social capital, which is represented by the material, instrumental, affective, and informative contributions, real or perceived, provided by family, friends, the community, and formal institutions (Fernández, 2005; Guzmán et al., 2002) (Figure 1).

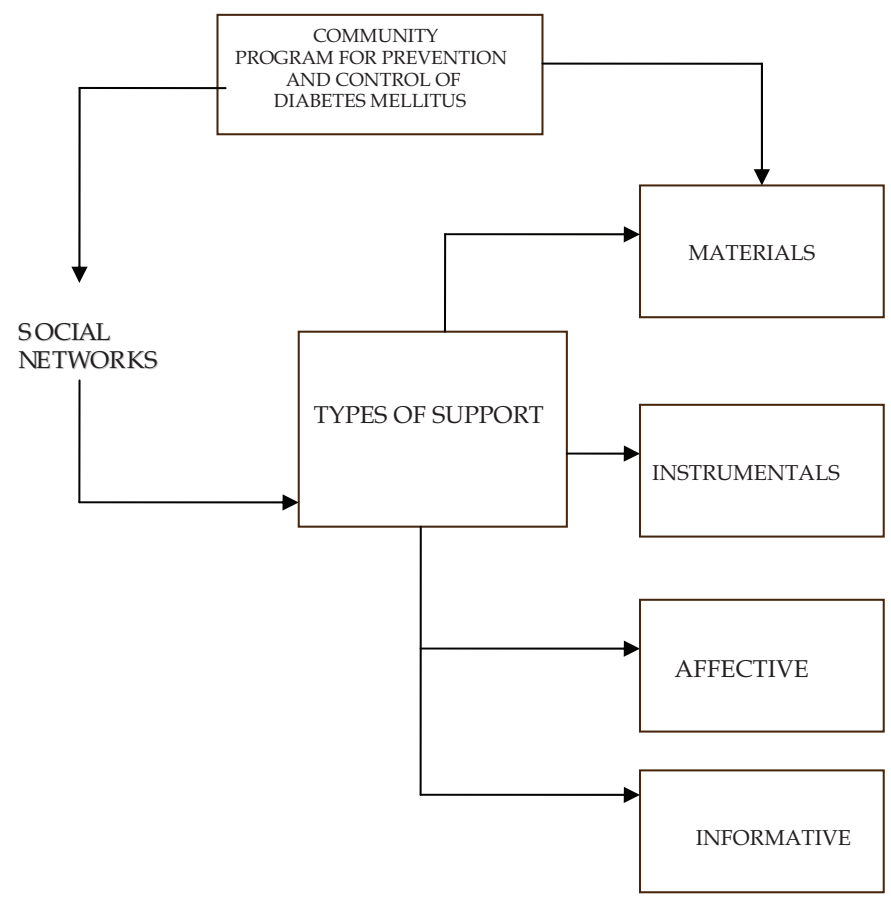

Fig. 1. Types of support that individuals can offer through social networks of social support in Community Programs for prevention and control of Diabetes Mellitus..

\section{Program}

Among elements to measure social networks, we find size, density, reciprocity, family relationship, homogeneity, type of support received, and social network analysis is approached through individualized description and the application of standardized instruments (Kloseck, 2007; Mendoza-Núñez \& Martínez-Maldonado, 2009b).

Reciprocity is the key element of social networks and assumes that when support is requested from the social support network, the individual is aware that he/she, too, is a 
potential element of support for the group (Dabas \& Perrone, 1999). Likewise, it is proposed that the social network wields an influence on health-related habits, because the individual is more likely to adopt healthy lifestyles if he/she has someone to share these with, and, on the other hand, internalization of the norms of behavior that the family, friends, and the community group offer can be of significant influence. In addition, the social control that is exercised by means of regulations, sanctions, or interventions can also exert an influence on attitudes and changes in conduct (Arechabala \& Miranda, 2002). Therefore, a suitable social network is considered as an open, multicenter system made up of informal (family, friends, community) and formal components (professional and institutional), with defined objectives and goals framed within a program that, through the empowerment of individuals, achieves maximal health and well-being according to their sociocultural context. At present, it is recognized that one of the basic strategies for the prevention and control of diabetes mellitus is the establishment, coordination, and monitoring of social support networks as part of public policy (Mendoza-Núñez et al., 2009b).

Social support networks are a potential source of well-being and health, because health can be transmissible and the vehicle is the social support network.

\section{Empowerment and health}

Empowerment is defined as a process of participative development by means of which individuals, communities, and organizations achieve greater control over their lives and environment, acquiring rights and new life goals, in addition to a reduction of social marginalization (Kar, 1999; Anderson \& Funnell, 2005; Maton, 2008). Empowerment involves self-strengthening, control, self-power, self-confidence, making decisions of one's own accord, a fitting life according to one's values, the capacity to fight for one's rights, independence, to the right to make one's own decisions. It is noteworthy that empowerment is relevant at the individual as well at the collective level (Ho et al., 2010).. In this regard, in order to exercise empowerment in an efficient and efficacious manner, it is indispensible to consider four key elements (Narayan, 2002):

i. Access to information. Information is power; it is in this way that informed citizens have more opportunities to access to services, to exercise their rights, and to ensure that non-governmental as well as governmental actors respond to their needs;

ii. Inclusion and participation. Individuals should be included in decision-making to ensure that the use of public and private resources responds to the real needs of the population.

iii. Responsibility or rendering of accounts. Public servants and those responsible for Nongovernmental organizations (NGOs) should respond for their policies, actions, and the use of funds.

iv. Local organizational capacity. The population should possess the ability to organize itself and to work in a group, with the goal of participating actively in the community intervention programs that are developed in its milieu.

On the other hand, the importance has been highlighted of empowerment for the detection of chronic diseases according to the biopsychosocial model and patient-centered care, demonstrating that active participation of the individual is fundamental for to achieving maximum well-being and QOL at different ages and within different contexts (Salmon, 2003; Savage et al., 2006). 
The main methods employed at the community level to achieve empowerment are the following (Kar, 1999): a) training for empowerment and the development of leadership; b) support for the establishment of policies and aid programs; c) public education and opinion for sources of support; d) the organization of associations; e) cooperative unions for the creation of empowerment collectives; f) empowerment for work and microentrepreneurs to achieve autonomy and control of their situation, and h) the protection of rights and social action for legislation to benefit specific groups.

Empowerment within the framework of health promotion considers motivation for action, empowerment-oriented support, individual participative actions, and an empowerment program for its institutionalization and replication (Maton, 2008). Likewise, it has been recognized that education is basic for achieving empowerment (Aujoulat et al., 2007). It has also been cited that social and educational activity in community interventions avoids isolation (Cattan, 2005).

The model contemplates a Community United for Human Growth (CUHG), whose purpose is to coordinate the large net of social networks of mutual-aid groups, in which self-care is a daily practice for the prevention and control of diabetes mellitus, as well as for achieving maximal well-being and health as components of one's human development (Figure 2).

Participation of the population aged 45 years and over (diabetics and non-diabetics) is considered, in that the common objective is to establish strategies for the individual to continue his/her integral human development. One of the determining factors for lack of control of chronic diseases, and especially for diabetes mellitus, comprises the prejudices and stereotypes that deriving form lack of information, which leads to negation of the disease and abandonment of treatment, or resorting to "miraculous or cure-all" treatments.

On the other hand, it has been demonstrated that apathy is one of the principal difficulties for the population in its adoption of healthy lifestyles for chronic disease prevention and control (Padala et al., 2008).

Thus, our proposal establishes the elimination of the stigma of the disease and proposes a model of community intervention for integral human development in which maintenance of health constitutes the key factor. This model avoids the social prejudices that label "groups of diabetics as sick people who do not follow the rules", which generates social rejection and abandonment of the group in many participants, who "seek at all times the cure for their incurable disease" in order to "stop being part of the group of diabetics".

In 1996, our research group proposed a community care model, considering the active participation of the individual in order to achieve maximum QOL in their social milieu (Mendoza-Núñez et al., 1996). In this respect, although the results have been satisfactory, we adapted the model in 2004 according to the paradigm of active aging and subsequently submitted this to a process of investigation to determine its feasibility and pertinence (Martínez-Maldonado et al., 2007). As previously mentioned, our proposal is not limited to older adults, because the principles and strategies can be applied to adult population in general.

The model establishes as the key element the formation of promoters of integral human development. In this regard, promoters function as mutual aid-group coordinators, establishing self-care and self-management actions for their members' well-being and social development, in which health maintenance is fundamental.

Self-care, mutual aid, and self-management constitute the basic strategic elements for the model proposed, and the former are closely linked; thus, we are unable to propose these in 


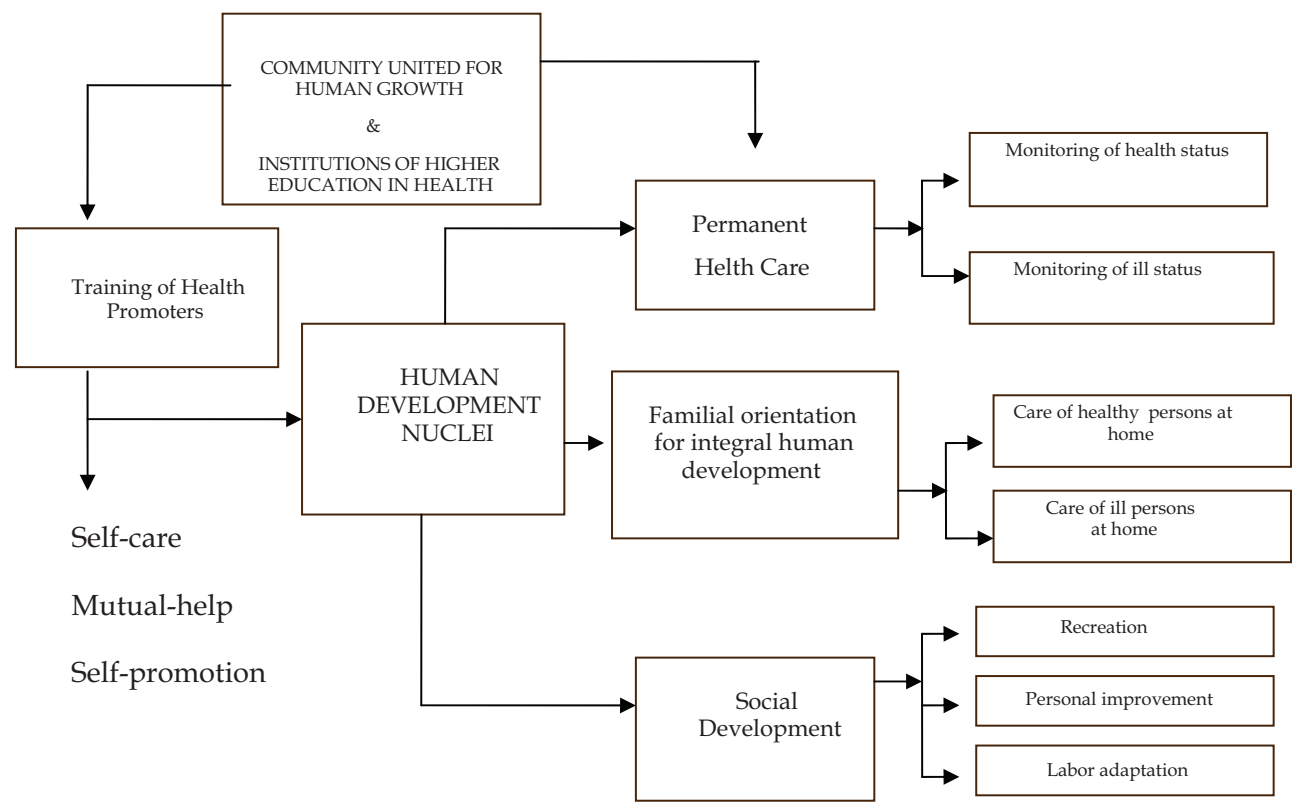

Fig. 2. Community Participation Model for Prevention and Control of Diabetes Mellitus. Community United for Human Growth linked to Institutions of Higher Education in Health is responsible for the design and implementation of educational programs and guides the training of the health promoters for the development of mutual-help groups (human development nucleus). A human development nuclei is a group integrated by 10 to 15 adults of nearby communities with similar interests. They are mainly involved in the practice of self-care, mutal-help, and self-promotion guidelines established by the program. The model is addressed toward the following objectives: (i) the supervision of the health status of participants in the program; (ii) the training of qualified health care promoters, certified on the basis of a formal continuous education program offered by a renowned academic institution; (iii) to provide orientation and guidance to families with regard to basic care practices with both healthy and sick adults; (iv) to promote the social and human development of the populations in Mexico.

isolated fashion. Therefore, any community program directed toward human development in which maintenance of health and improving QOL are considered should establish the mechanisms that allow for its harmonic and complementary execution. In this sense, knowledge, attitudes, and behaviors required for adequately exercising self-care, mutual aid, and self-management require the formal training of the persons who function as leaders and who promote the active participation of the members of mutual-aid groups (Song, 2010).

Self-care refers to the reasoned behavior of the individual with a theoretical basis that allows him/her to decide on and act upon the prevention, diagnosis, and treatment of acute and chronic diseases, as well as in maintenance of health and maximum enjoyment of their QOL, according to their sociocultural context, utilizing formal and informal social support networks in optimal fashion. Similarly, mutual aid includes the reasoned and requisite 
behavior that a group of individuals who share similar problems and who are aware of the advantages and commitments acquired adopts on voluntarily accepting to be part of the group. With regard to self-management, this involves the actions that an individual or selfhelp group performs in an autonomous manner, in an expected and optimal way, taking into consideration the elements and mechanisms of formal and informal social support networks.

The CUHG is one of the elements of the social support network, responsible for training Human Development Promoters (HDP), who are in turn responsible for coordinating mutual-aid groups denominated Human Development Nuclei (HDN), which are made up of 10 to 15 adults groups according to their affinities and the geographical closeness to their domiciles. HDN function under the directorates of self-care, -help, and -management.

The model's established pillars are:

- Permanent monitoring of the health state: The fundamental objective of this is to maintain, prolong, and recover health, as well as to improve the individual's selfperception of psychosocial well-being, according to his/her physical condition and sociocultural milieu. For this, self-care programs should be implemented for the healthy and sick individual, with pre-established evaluation, surveillance, and primary careaction protocols.

- Formation of Human Development Promoters: The CUHG, supported by an educative institution, is responsible for the formation of HDP, following a formal academic program, considering continuous education and a certification of the topicality and pertinence of the knowledge imparted.

- Familial orientation for integral human development: HDP possess sufficient knowledge to orient and train the individual's relatives to provide support for the psychosocial development of their family members, considering the basic skills for the care of the healthy and sick individual in the home.

- Adaptation and social development: The model took into consideration among its goals that adults would enjoy their situation to the maximum, taking into consideration their human life-cycle stage and sociocultural conditions. Thus, we recommend the implantation of programs of recreation, adaptation, and psychosocial and occupational self-improvement under an anthropological focus, according to the individual's interests, age, schooling, gender, health state, socioeconomic situation, etc.

The model establishes flexible general guidelines that could be adopted for rural and urban population, as well as for groups of adults of different sociocultural and economic conditions.

As an integral part of the model, the implementation has been established of a "Healthy Life" Program in which, under a constructivist focus, participants establish the strategies for adopting healthy lifestyles, utilizing a self-efficacy instrument to maintain and strengthen behavioral changes.

\section{Model viability}

The model has been implemented in Mexico with an older adult population from rural and urban areas. Notwithstanding this, as mentioned previously, its application is not limited to this age group (Mendoza-Núñez et al., 2009b).

Among the most relevant aspects of the model, we find that community groups are not labeled with "groups of diabetics" stigma. In this regard, it has been proposed that 
unfundamented social representations of diabetes leads to prejudices on and negative stereotypes of the disease (Torres-López et al., 2005) that affect self-esteem, causing apathy, rejection, and abandonment of the "groups of diabetics" (Padala et al., 2008).

On the other hand, the anthropological aspects associated with the disease should be considered in community interventions, because cultural aspects determine negative lifestyles (sedentary life style and inadequate nutrition), which raises the risk of diabetes mellitus (Martorell, 2005).

For this reason, the purpose of our model is the conformation and integration of a "great network of networks" of mutual-aid groups who practice scientifically founded principles of daily self-care and self-management for their human development. In this light, the prevention of chronic diseases, and especially diabetes mellitus, constitutes one of the basic objectives.

Our experience in the application of the model demonstrates that it is viable in the technical and operative ambits at the community level; notwithstanding this, the most important weakness of the model lies in the discrepancy of its participative focus with State Social Development and Health Programs, in which neither empowerment nor the active participation of the population are considered, which generates frustration and, occasionally, program abandonment.

\section{Healthy lifestyles and diabetes mellitus}

Healthy lifestyles constitute key elements for preventing and controling DM. In this regard, it has been amply demonstrated that the periodic practice of physical exercise together with a healthy diet for a minimum of 2 years significantly diminishes the blood concentration of glucose, triglycerides, and cholesterol, and body weight, and increase the levels of High density lipoprotein (HDL) cholesterol, significantly diminishing the risk for metabolic syndrome, diabetes mellitus, and their complications (Steyn et al., 2004; Schulze \& Hu, 2005; Barclay et al., 2008; Brown et al., 2009). Although the effectiveness of healthy lifestyles is known for the prevention and control of DM, the problematic resides in achieving the adoption and maintenance of the population of compliance with these lifestyles, In this respect, it has been cited that to maintain healthy lifestyles, the strategies should not be limited to the individual, but instead, should involve the family, the workplace, and community networks, in addition to the establishment of social reinforcement programs (Bazzano, 2005; Teufel-Shone et al., 2005; Toft et al., 2007; Marrero, 2009).

Among the factors linked with compliance with healthy lifestyles, we are able to highlight selfefficacy and self-esteem. In this regard, self-efficacy is a determining factor for self-care for DM (Johnston-Brooks et al., 2002; Hankonen et al., 2009). Similarly, low self-esteem and depression are factors related with low community participation for DM self-care (Fortmann et al., 2010). In general, a healthy diet that is recommended comprises consuming three to five servings of fruits and vegetables daily and decreasing the consumption of foods rich in saturated fats and refined sugars. Nonetheless, it is important to cite that these recommendations should be adapted to age, gender, occupation, health state, socioeconomic level, food preferences, and food availability. In this respect, one of the errors observed in our environment in community programs for the prevention and control of DM is the recommendation of diets that are not accessible to the economic situation or that have discrepancies with food preferences, which occasions the non-compliance of persons with the program or program abandonment soon after beginning it (Mendoza-Núñez et al., 2008) 
On the other hand, the practice of moderate physical exercise with a duration of $50 \mathrm{~min}$ daily for a minimum of 5 days weekly has biochemical, psychological, and social benefits (Caspersen et al., 1985; Laitakari, 1996); notwithstanding this, some cultural aspects that are linked with incorrect beliefs determine to a great extent the resistance of the population to adopting and maintaining this lifestyle, thus the need to establish strategies that respond to the sociocultural context (Marcus et al., 2000; Di Loreto et al., 2003).

\section{Conclusion}

The proposed model of community participation for the prevention and control of diabetes mellitus establishes as fundamental elements a broad concept of health, the concepts of citizenship and empowerment, and as self-care strategies, mutual aid and self-management with the support of social networks. Similarly, the model possesses several characteristics that distinguish it. In the first place is its versatility, because it can be adapted to different populations; in second place, its inclusion for the functioning of a program that is based on the recovery of the daily knowledge of persons with the aim of constructing new knowledge from these; the inclusion of subprograms of relevant aspects for achieving empowerment and disease control, while the integral development of persons is another characteristic that makes the model different from others and that eliminates the disease stigma, another of its benefits.

This model represents important savings of economic resources for the State.

Finally, to strengthen the viability of the model, it is indispensable that the State establish public policies that permit the development of this type of model.

\section{Acknowledgments}

This work was supported by Consejo Nacional de Ciencia y Tecnología FONSEC SSA/IMSS/ISSSTE S0008-2008-1, Grant 87139, and Instituto para la Atención de los Adultos Mayores del Estado de Hidalgo (IAAMEH), México.

\section{References}

Anderson, R.M., Funnell, M.M. (2005). Patient empowerment: reflections on the challenge of fostering the adoption of a new paradigm. Patient Education and Counseling; 57(2):153-157.

Arechabala, M. M. C. \& Miranda, C. C. (2002). Validación de una escala de apoyo social percibido en un grupo de adultos mayores adscritos a un programa de hipertensión de la región metropolitana. Ciencia y Enfermería; 8: 49-55.

Aujoulat, I., d'Hoore. W. \& Deccache, A. (2007). Patient empowerment in theory and practice: polysemy or cacophony?. Patient Education and Counseling; 66(1):13-20.

Barclay, C., Procter, K.L., Glendenning, R., Marsh, P., Freeman, J. \& Mathers, N. (2008). Can type 2 diabetes be prevented in UK general practice? A lifestyle-change feasibility study (ISAIAH). British Journal of General Practice; 58(553):541-547.

Barr, V.J., Robinson, S., Marin-Link, B., Underhill, L., Dotts, A., Ravensdale, D. \& Salivaras, S. (2003). The expanded Chronic Care Model: an integration of concepts and strategies from population health promotion and the Chronic Care Model. Hospital Quarterly;7(1):73-82. 
Battersby, M., Von Korff, M., Schaefer, J., Davis, C., Ludman, E., Greene, S.M., Parkerton, M. \& Wagner, E.H. (2010). Twelve evidence-based principles for implementing selfmanagement support in primary care. Joint Commission Journal on Quality and Patient Safety; 36(12):561-570.

Bazzano, L.A., Serdula, M. \& Liu, S. (2005). Prevention of type 2 diabetes by diet and lifestyle modification. Journal of the American College of Nutrition; 24(5):310-319.

Brown, T., Avenell, A., Edmunds, L.D., Moore, H., Whittaker, V., Avery, L. \& Summerbell, C. (2009). Systematic review of long-term lifestyle interventions to prevent weight gain and morbidity in adults. Obesity Reviews; 10(6):627-638.

Burt, R. S. (1997). A note on social capital and network content. Social Networks; 19: 355-373.

Caponi, S. (1997). Georges Canguilhem y el estatuto epistemológico del concepto de salud. História, Ciências, Saúde - Manguinhos; IV (2):287-307.

Caspersen, C.J., Powell, K.E. \& Christenson, G.M. (1985). Physical activity, exercise, and physical fitness: definitions and distinctions for health-related research. Public Health Reports;100(2):126-131.

Castillo, A., Giachello, A., Bates, R., Concha, J., Ramirez, V., Sanchez, C., Pinsker, E. \& Arrom, J.(2010). Community-based diabetes education for Latinos: The Diabetes Empowerment Education Program. Diabetes Educator;36(4):586-594.

Cattan, M., White, M., Bond, J. \& Learmouth, A. (2005) Preventing social isolation and loneliness among older people: a systematic review of health promotion interventions. Ageing \& Society; 25: 41-67.

Ciccone, M.M., Aquilino, A., Cortese, F., Scicchitano, P., Sassara, M., Mola, E., Rollo, R., Caldarola, P., Giorgino, F., Pomo, V. \& Bux, F. (2010). Feasibility and effectiveness of a disease and care management model in the primary health care system for patients with heart failure and diabetes (Project Leonardo). Vascular Health and Risk Management; 6:297-305.

Contandriopoulos, A.-P. (2006). Elementos para una "topografía" de concepto de la Salud. Ruptures, Revista Interdisciplinaria de la Salud; 11 (1): 86-99.

Chapela, M. C. (2008a). Promoción de la salud para la disminución del riesgo y el cuidado de las enfermedades crónicas. En: Mendoza-Núñez, V., Sánchez-Rodríguez y Correa-Muñoz, E. Estrategias para el Control de enfermedades crónicodegenerativas a nivel comunitario: México: FES Zaragoza, UNAM. p. 23-45.

Chapela, M.C. (2008b). Una definición de salud para promover la salud. En: Martínez (coord.) Seis miradas sobre la salud y sus relaciones con el mundo social. México: Universidad Autónoma Metropolitana. p. 13-33.

Dabas, E. \& Perrone, N. (1999). Redes en salud. FUNCER. Disponible en: http://www.pasteur.secyt.gov.ar/formadores/RedSal-Dabas-Perrone.pdf

Di Loreto, C., Fanelli, C., Lucidi, P., Murdolo, G., De Cicco, A., Parlanti, N., Santeusanio, F., Brunetti, P. \& De Feo, P. (2003). Validation of a counseling strategy to promote the adoption and the maintenance of physical activity by type 2 diabetic subjects. Diabetes Care;26(2):404-408.

Eslava-Castañeda, J.C. (2006). Repensando la promoción de la salud en el sistema general de seguridad social en salud. Revista de Salud pública; 8 (Sup. 2): 106-115.

Fernandez, P. R. (2005) Redes sociales, apoyo social y salud. Periferia, 3. Disponible en: www.periferia.name 
Fortmann, A.L., Gallo, L.C., Walker ,C. \& Philis-Tsimikas, A. (2010). Support for disease management, depression, self-care, and clinical indicators among Hispanics with type 2 diabetes in San Diego County, United States of America. Revista Panamericana de Salud Pública; 28(3):230-234.

Gagliardino, J.J. \& Etchegoyen, G. (2001). A model educational program for people with type 2 diabetes. Diabetes Care; 24:1001-1007.

Giachello, A.L., Arrom, J.O., Davis, M., Sayad, J.V., Ramirez, D., Nandi, C., Ramos, C. \& Chicago Southeast Diabetes Community Action Coalition. (2003). Reducing diabetes health disparities through community-based participatory action research: the Chicago Southeast Diabetes Community Action Coalition. Public Health Reports;118(4):309-323.

Glasgow, R.E., Orleans, C.T. \& Wagner, E.H. (2001). Does the chronic care model serve also as a template for improving prevention?. Milbank Quarterly;79(4):579-612, .

Gómez-Arias, R. D., González, E. (2004). Evaluación de la prevención de la enfermedad y la promoción de la salud: Factores que deben considerarse. Revista Facultad Nacional de Salud Pública 20; 22 (1):87-106.

Guzmán, J. M., Huenchuan, S. \& Montes de Oca, V. (2002). Redes de apoyo social de las personas mayores: marco conceptual. Santiago de Chile: CEPAL. Disponible en: http://www.eclac.cl/publicaciones/xml/0/14200/lclg2213_p2.pdf

Hankonen, N., Absetz, P., Haukkala, A. \& Uutela, A. (2009). Socioeconomic status and psychosocial mechanisms of lifestyle change in a type 2 diabetes prevention trial. Annals of Behavioral Medicine;38(2):160-165.

Ho, A.Y., Berggren, I. \& Dahlborg-Lyckhage, E. (2010). Diabetes empowerment related to Pender's Health Promotion Model: a meta-synthesis. Nursing $\mathcal{E}$ Health Sciences;12(2):259-267.

Horowitz, C.R., Robinson, M. \& Seifer, S. (2009). Community-based participatory research from the margin to the mainstream: are researchers prepared?. Circulation; 19;119:2633-2642.

International Diabetes Federation (2011). Prevalence of diabetes mellitus in the world. Diabetes Facts. http://www.idf.org/

Jenkins, C., Pope, C., Magwood, G., Vandemark, L., Thomas, V., Hill, K., Linnen, F., Beck, L.S. \& Zapka, J. (2010). Expanding the chronic care framework to improve diabetes management: the REACH case study. Progress in community health partnerships; $4(1): 65-79$.

Johnston-Brooks, C.H., Lewis, M.A. \& Garg, S. (2002). Self-efficacy impacts self-care and HbA1c in young adults with Type I diabetes. Psychosomatic Medicine;64(1):43-51.

Kar, S.B., Pascual, C.A. \& Chickering, K.L. (1999). Empowerment of women for health promotion: a meta-analysis. Social Science E Medicine; 49: 1431-1460.

Kloseck, M. (2007). The use of Goal Attainment Scaling in a community health promotion initiative with seniors. BMC Geriatrics, 7:16. Available from: http://www.biomedcentral.com/1471-2318/7/16

Laitakari, J., Vuori, I. \& Oja, P. (1996). Is long-term maintenance of health-related physical activity possible? An analysis of concepts and evidence. Health education research;11(4):463-477. 
Llopis, C. J. (2005). Redes sociales y apoyo social. Una aproximación a los grupos de autoayuda.Periferia; 3. Disponible en: www.periferia.name

Marcus, B.H., Dubbert, P.M., Forsyth, L.H., McKenzie, T.L., Stone, E.J., Dunn, A.L. \& Blair, S.N. (2000) Physical activity behavior change: issues in adoption and maintenance. Health Psychology 19(1 Suppl):32-41.

Marrero, D.G. (2009). The prevention of type 2 diabetes: an overview. Journal of Diabetes Science and Technology;3(4):756-760.

Martínez-Maldonado, M.L., Correa-Muñoz, E. \& Mendoza-Núñez, V.M. (2007). Program of active aging in a rural Mexican community: a qualitative approach. BMC Public Health; 7:276.

Martorell, R. (2005). Diabetes and Mexicans: why the two are linked. Preventing Chronic Disease. Available from: URL: http://www.cdc.gov/pcd/issues/2005/jan/pdf/04_0100.pdf

Maton, K.I. (2008). Empowering community settings: agents of individual development, community betterment, and positive social change. American Journal of Community Psychology; doi 10.1007/s10464-007-9148-6.

Mendoza-Núñez, V.M., Correa-Muñoz, E., Sánchez-Rodríguez, M. \& Retana-Ugalde, R. (1996). Modelo de atención de núcleos gerontológicos. Geriatrika; 12: 15-21.

Mendoza-Núñez, V.M., Sánchez-Rodríguez, M.A. \& Correa-Muñoz, E. (2008). Estrategias para el control de enfermedades crónico-degenerativas a nivel comunitario. México: FES “ZARAGOZA”, UNAM.

Mendoza-Núñez, V.M., Martínez-Maldonado, M.de L. \& Correa-Muñoz, E. (2009a). Implementation of an active aging model in Mexico for prevention and control of chronic diseases in the elderly.BMC Geriatrics; 26;9:40.

Mendoza-Núñez, V.M. \& Martínez-Maldonado, M. (2009b). Escala de Redes de Apoyo Social para Adultos Mayores (ERASAM). En: A. L. González-Celis, R. [Coord.]. Evaluación en Psicogerontología. México: Editorial Manual Moderno. p. 95-112.

Mendoza-Núñez, V.M., \& Rosado-Pérez, J. (2010). Aging, diabetes mellitus and overweight. In: Hiriart-Urdanivia, M. \& Mas-Oliva, J. Advances in obesity-diabetes research at UNAM. México: Manual Moderno/PUIS, UNAM. p. 79-102.

Narayan, D. (2002) Empoderamiento y reducción de la pobreza. México: Banco Mundial /Alfaomega Grupo Editor. p. 1-13.

Parchman, M.L., Pugh, J.A., Wang, C.P. \& Romero, R.L. (2007). Glucose control, self-care behaviors, and the presence of the chronic care model in primary care clinics. Diabetes Care 30:2849-2854.

Padala, P.R., Desouza, C.V., Almeida, S., Shivaswamy, V., Ariyarathna, K., Rouse, L., Burke, W.J. \& Petty, F. (2008). The impact of apathy on glycemic control in diabetes: a cross-sectional study. Diabetes Research and Clinical Practice ;79(1):37-41.

Piatt, G.A., Orchard, T.J., Emerson, S., Simmons, D., Songer, T.J., Brooks, M.M., Korytkowski, M., Siminerio, L.M., Ahmad, U. \& Zgibor, J.C. (2006). Translating the chronic care model into the community: results from a randomized controlled trial of a multifaceted diabetes care intervention. Diabetes Care; 29(4):811-7.

Restrepo, H. (2001). Conceptos y definiciones. En: Restrepo H. y Málaga, H. Promoción de la Salud: Cómo construir vida saludable. Bogotá: Editorial Médica Panamericana.p.24-33. 
Salmon, P. \& HalI, G.M. (2003). Patient empowerment and control: a psychological discourse in the service of medicine. Social Science \& Medicine; 57: 1969-1980.

Santos-Burgoa, C., Rodríguez-Cabrera, L., Rivero, L., Ochoa, J., Stanford, A., Latinovic, L. \& Rueda, G. (2009). Implementation of Mexico's Health Promotion Operational Model. Preventing chronic disease; 6(1).

Available from: URL http://www.cdc.gov/pcd/issues/2009/jan/pdf/08_0085.pdf

Savage, C.L., Xu, Y., Lee, R., Rose, B.L., Kappesser, M. \& Anthony, J.S. (2006). A case study in the use of community-based participatory research in public health nursing. Public Health Nursing;23(5):472-478.

Schulze, M.B. \& Hu, F.B. (2005). Primary prevention of diabetes: what can be done and how much can be prevented?. Annual Review of Public Health; 26:445-467.

Shephard, M.D., Mazzachi, B.C., Shephard, A.K., McLaughlin, K.J., Denner, B. \& Barnes, G. (2005). The impact of point of care testing on diabetes services along Victoria's Mallee Track: results of a community-based diabetes risk assessment and management program. Rural Remote Health; 5(3):371.

Song, M. (2010). Diabetes mellitus and the importance of self-care. Journal of Cardiovascular Nursing; 25(2):93-8.

Steyn, N.P., Mann, J., Bennett, P.H., Temple, N., Zimmet, P., Tuomilehto, J., Lindström, J. \& Louheranta, A. (2004). Diet, nutrition and the prevention of type 2 diabetes. Public Health Nutrition;7(1A):147-165.

Strickland, P.A., Hudson, S.V., Piasecki, A., Hahn, K., Cohen, D., Orzano, A.J., Parchman, M.L. \& Crabtree, B.F. (2010). Features of the Chronic Care Model (CCM) associated with behavioral counseling and diabetes care in community primary care. Journal of the American Board of Family Medicine; 23: 295-305.

Teufel-Shone, N.I., Drummond, R., Rawiel, U. (2005). Developing and adapting a familybased diabetes program at the U.S.-Mexico border. Prev Chronic Dis [serial online]. Available from: URL: http://www.cdc.gov/pcd/issues/2005/jan/04_0083.htm

Toft, U.N., Kristoffersen, L.H., Aadahl, M., von Huth Smith, L., Pisinger, C. \& Jørgensen, T. (2007). Diet and exercise intervention in a general population--mediators of participation and adherence: the Inter99 study. European Journal of Public Health; 17(5):455-463.

Torres-López, T.M., Sandoval-Díaz, M. \& Pando-Moreno, M. (2005). "Blood and sugar": social representations of diabetes mellitus by chronic patients in Guadalajara, Mexico. Cadernos de Saúde Pública;21(1):101-110.

Villalpando, S., Rojas, R., Shamah-Levy, T., Ávila, M.A., Gaona, B., De la Cruz, V., Rebollar, R. \& Hernández, L.. (2010a). Prevalence and distribution of type 2 Diabetes mellitus in Mexican adult population. A probabilistic survey. Salud Pública de México;52 (suppl 1):S19-S26.

Villalpando, C.G., Ridaura, R.L., Ponce, E.L. \& Villalpando, M.E. (2010b). And now what? Time for daring innovation. Salud Pública de México.;52 (Suppl 1):S80-83.

Wagner, E.H., Austin, B.T. \& Von Korff, M. (1996). Organizing care for patients with chronic illness. Milbank Quarterly; 74(4):511-544.

Wagner, E.H., Davis, C., Schaefer, J., Von Korff, M. \& Austin, B. (1999). A survey of leading chronic disease management programs: are they consistent with the literature? Managed Care Quarterly; 7(3):56-66. 
World Health Organization. (1986). Ottawa Charter for Health Promotion. Geneva: WHO/HPR/HEP/95.1.WHQ. 


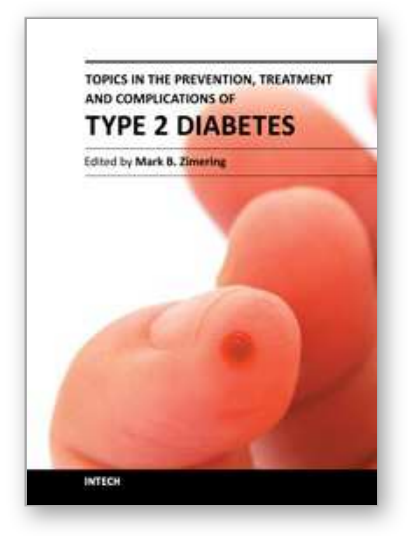

\author{
Topics in the Prevention, Treatment and Complications of Type 2 \\ Diabetes \\ Edited by Prof. Mark Zimering
}

ISBN 978-953-307-590-7

Hard cover, 340 pages

Publisher InTech

Published online 04, November, 2011

Published in print edition November, 2011

Type 2 diabetes is estimated to affect 120 million people worldwide- and according to projections from the World Health Organization this number is expected to double over the next two decades. Novel, cost-effective strategies are needed to reverse the global epidemic of obesity which is driving the increased occurrence of type 2 diabetes and to less the burden of diabetic vascular complications. In the current volume, Topics in the Prevention, Treatment and Complications of Type 2 Diabetes, experts in biology and medicine from four different continents contribute important information and cutting-edge scientific knowledge on a variety of topics relevant to the management and prevention of diabetes and related illnesses.

\title{
How to reference
}

In order to correctly reference this scholarly work, feel free to copy and paste the following:

Victor Manuel Mendoza-Núñez, Maria de la Luz Martinez-Maldonado and Elsa Correa-Muñoz (2011). Community Participation Model for Prevention and Control of Diabetes Mellitus, Topics in the Prevention, Treatment and Complications of Type 2 Diabetes, Prof. Mark Zimering (Ed.), ISBN: 978-953-307-590-7, InTech, Available from: http://www.intechopen.com/books/topics-in-the-prevention-treatment-andcomplications-of-type-2-diabetes/community-participation-model-for-prevention-and-control-of-diabetesmellitus

\section{INTECH}

open science | open minds

\author{
InTech Europe \\ University Campus STeP Ri \\ Slavka Krautzeka 83/A \\ 51000 Rijeka, Croatia \\ Phone: +385 (51) 770447 \\ Fax: +385 (51) 686166 \\ www.intechopen.com
}

\author{
InTech China \\ Unit 405, Office Block, Hotel Equatorial Shanghai \\ No.65, Yan An Road (West), Shanghai, 200040, China \\ 中国上海市延安西路65号上海国际贵都大饭店办公楼 405 单元 \\ Phone: +86-21-62489820 \\ Fax: +86-21-62489821
}


(C) 2011 The Author(s). Licensee IntechOpen. This is an open access article distributed under the terms of the Creative Commons Attribution 3.0 License, which permits unrestricted use, distribution, and reproduction in any medium, provided the original work is properly cited. 